\title{
Toxicity Studies of Ametryne to Land and Aquatic Organisms
}

\author{
Ana Paula Justiniano Régo \& Ederio Dino Bidoia \\ State University of Sao Paulo, Brazil \\ E-mail: anapjustiniano@gmail.com \\ Cassiana Maria Reganhan-Coneglian \\ State University of Campinas, Brazil
}

Received: August 2, 2016 Accepted: August 20, 2016 Published: December 6, 2017

doi:10.5296/ast.v6i1.9828 URL: httpV.//doi.org/10.5296/ast.v6i1.9828

\begin{abstract}
The ametryne herbicide is largely used on sugar cane plantation in Brazil. It is persistent in the environment and can be found in bodies of water, impacting the aquatic and terrestrial ecosystems. Generally, in crops are applied mixtures of herbicides in order to obtain a higher success in combating weeds. This study evaluated the toxicity only of ametryne herbicide, without mixture with other herbicides, in order to quantify only the degree of dangerousness. This work evaluated the toxicity of ametryne to one aquatic test organism (Daphnia similis) and two land test organism (Eruca sativa and Lactuca sativa). Immobility of D. similis was evaluated in the presence of ametryne. Influences of ametryne on seed germination and root growth of E. sativa and L. sativa were evaluated. Even at low concentrations $(5.00 \mathrm{mg} / \mathrm{L})$, ametryne caused toxic effects on the mobility of $D$. similis, and $0.25 \mathrm{~g} / \mathrm{L}$ caused toxic effects on the seeds. Root growth and the percentage of inhibition showed greater sensitivity to ametryne compared with seed germination. Thus, ametryne resulted in toxic effects to the analyzed organisms, which may bring damage to both aquatic and terrestrial ecosystems.
\end{abstract}

Keywords: ametryne, ecotoxicity, soil, contamination

\section{Introduction}

Pesticides, used to control pests and weeds, are rarely found alone in the environment. Typically, they present a diversity on commercial formulations (Faust et al., 2003). Therefore, the organisms are not exposed to a single contaminant, but usually mixtures of contaminants (Kurth et al., 2015). Pesticides may reach non-target organisms through runoff or leaching, resulting in adverse effects to terrestrial ecosystem (Velki \& Ečimović, 2015), and influencing aquatic ecosystem by changing its structure biotic (Faust et al., 2003). 
When applied to the environment, the pesticides achieve the molecular portion of the body, resulting in a common toxicological pattern between different reactions that can affect it (Faust et al., 2003).

One of the adverse effects of pesticides is their environmental persistence. According to Bruzzoniti et al. (2006), the persistence in the environment depends on the applied dose, the chemical nature of the compound, soil characteristics, and hydro-geological characteristics of the contaminated area. The concentration of a compound at a certain place depends on its rate of degradation and transportation in the environment (Schwarzenbach et al., 2003). Malinowska \& Jankowski (2015) detected the presence of fungicides and insecticides in Achillea millefolium samples, an alarming fact as such plants are used for medicinal purposes.

Brazil is one of the largest food producers in the world, due to its large acreage and high productivity, and may be in the next decade the largest food exporter according to OCDE-FAO (2015). However, the large scale use of ametryne results in negative effects on the environment. Ametryne is difficult to be degraded by soil microorganisms due to an aromatic ring structure in its molecule, and can undergo leaching affecting aquatic organisms (Farré et al., 2002; Gao et al., 2009; Kasozi et al., 2012). Pfeuffer \& Rand (2004) detected ametryne in surface water and sediment samples in South Florida, United States. Koskine \& Harper (1990) detected the presence of triazine herbicide residues in Mélarchez waters on the island of Martinique, France. The presence of ametryne was detected in Brazilian waters (Botelho et al., 2015; Laabs et al., 2002).

The effect of toxic substances to the organisms depends on the applied dose and time of exposure to the products (Sánchez-Bayo, 2006). One of the representative organisms for aquatic ecotoxicological tests is Daphnia similis, which are a kind of crustaceans, the Cladocera order, commonly known as water fleas. They are ideal organisms for the evaluation of compounds in their physiology. They also have short life cycle and are easily handled (Herrera et al., 2014). Novelli et al. (2012) assess the potential toxicity of abamectin herbicide to $D$. similis, concluding that the herbicide was highly toxic to daphnids.

In addition, bioassays with vegetable seeds, such as Eruca sativa and Lactuca sativa, can be used to evaluate the phytotoxicity effects of pure compound or mixtures, during both germination and root development. (Sobrero \& Ronco, 2004). Studies with seeds of E. sativa have been evaluated for Malathion pesticide, being sensitive to the presence of the contaminant (Gafar et al., 2013).

This study evaluated the toxicity of ametryne only herbicide without mixing with other herbicides. This work evaluated the toxicity of ametryne to aquatic organism $D$. similis and the phytotoxicity to E. sativa and L. sativa seeds.

\section{Materials and Methods}

The assays were conducted with commercial ametryne herbicide $(500.00 \mathrm{~g} / \mathrm{L})$, from GESAPAX. The solutions were prepared with deionized water in laboratory scale, and the concentration gradients were set based on sugar cane field data. Concentrations of ametryne 
added in each test were shown in Table 1. 


\section{Macrothink}

Table 1. Concentrations used in ecotoxicological tests for each test organism.

\begin{tabular}{cc}
\hline Test organisms & Ametryne concentrations \\
\hline D. similis & $5.00 / 10.00 / 15.00 / 25.00 / 50.00 / 75.00 / 100.00 \mathrm{mg} / \mathrm{L}$ \\
E. sativa & $0.25 / 0.50 / 1.00 / 5.00 / 10.00 \mathrm{~g} / \mathrm{L}$ \\
L. sativa & $0.25 / 0.50 / 1.00 / 5.00 / 10.00 \mathrm{~g} / \mathrm{L}$ \\
\hline
\end{tabular}

\subsection{Toxicity test with D. similis}

Sighted toxicity test with $D$. similis was performed according to the technical standard ABNT (2004). Neonates of $D$. similis were used to evaluate the immobility of the organism. After 48 h exposure to ametryne, Median Effective Concentration (EC50) was calculated.

The tests were run in four replicates in containers with $10.0 \mathrm{ml}$ of sample and 5 neonates of $D$. similis. The containers were placed in trays, in the dark, at $20^{\circ} \mathrm{C}$, for $48 \mathrm{~h}$. The immotility of neonates in each container was observed. Farming water without ametryne was used as a negative control. The assay was performed in triplicate.

The percentage of each of immobility calculated using Eq. 1:

$$
\% \text { Immobility }=\frac{\text { average sample }}{\text { average negative control }} \times 100
$$

\subsection{Ametryne Phytotoxicity}

The seeds of the L. sativa and E. sativa were placed in sterile Petri plate. Each plate contained a filter paper with $10 \mathrm{~cm}$ diameter, 20 seeds equidistant organized on the filter surface. Each plate was added $3.00 \mathrm{ml}$ of ametryne concentrations. The plates were incubated in a BOD incubator (Marconi model MA 403) in absence of light at $22^{\circ} \mathrm{C}$ for $120 \mathrm{~h}$. The phytotoxicity test was adapted from the study Sobrero \& Ronco (2004). The assay was performed in triplicate. For the sensitivity tests, $3.00 \mathrm{ml}$ of $0.05 \mathrm{M}$ zinc sulphate (Synth) solution were used as positive control, and $3.00 \mathrm{~mL}$ of deionized water as negative control.

At the end of each test, the length of the germinated roots was measured. The percentage of root growth inhibition rate was evaluated using Eq. 2:

$$
\% \text { Inhibition }=\frac{(\text { average negative control-average treatment })}{\text { average negative control }} \times 100
$$

\subsection{Statistical Analysis}

For D. similis toxicity tests, Trimmed Spearman-Karber method (Hamilton et al., 1977) was used for statistical analysis, expressing the results in a concentration that causes $50 \%$ effect on organisms, CE50. For the tests with seed E. sativa and L. sativa, Tukey's test was used at $5 \%$ probability. 


\section{IIMacrothink}

Aquatic Science and Technology

ISSN 2168-9148 2018, Vol. 6, No. 1

Differences were considered statistically significant at $p$ value $<0.05$, using OriginPro 8.0 software developed by Origin Lab Corporation, for the Bartha and Pramer respirometric method.

\section{Results}

\subsection{Assessment of the ametryne's toxicity to D. similis}

All tested concentrations caused inhibitory effects on D. similis after $48 \mathrm{~h}$ exposure. After this period, the immobility percentages in the presence of ametryne was calculated. The results were shown in Table 2.

Table 2. Details of the concentrations used and obtained immobility percentages.

\begin{tabular}{cc}
\hline $\begin{array}{c}\text { Ametryne } \\
\text { concentrations } \\
(\mathbf{m g} / \mathbf{L})\end{array}$ & $\begin{array}{c}\text { Organism immobility } \\
(\boldsymbol{\%})\end{array}$ \\
\hline Control & 0 \\
5.00 & 5 \\
10.00 & 15 \\
15.00 & 30 \\
25.00 & 45 \\
50.00 & 100 \\
75.00 & 100 \\
100.00 & 100 \\
\hline
\end{tabular}

Through statistical test Trimmed Spearman-Karber, it was observed that the EC50 of ametryne for D. similis was $25.73 \mathrm{mg} / \mathrm{L}$.

It can be seen that with the ametryne concentration increasing, the amount of living organisms after $48 \mathrm{~h}$ exposure decreased. Negative effects were not observed in the control group, with $0 \%$ immobility. Thus, the effect that $D$. similis suffered was due to the presence of ametryne in water.

In the $10.00 \mathrm{mg} / \mathrm{L}$ concentration of herbicide, $15 \%$ organisms suffered toxic effects assessed by lack of mobility. In the $50.00 \mathrm{mg} / \mathrm{L}$ concentration all organisms presented immobility after $48 \mathrm{~h}$ exposure. In groups from $50.00 \mathrm{mg} / \mathrm{L}$ to $100.00 \mathrm{mg} / \mathrm{L}$, all the $D$. similis suffered toxic effects of ametryne molecule.

There was an increase in immobility of $D$. similis between $5.00 \mathrm{mg} / \mathrm{L}$ and $10.00 \mathrm{mg} / \mathrm{L}$ concentrations. From the concentrations of $5.00 \mathrm{mg} / \mathrm{L}$ to $25.00 \mathrm{mg} / \mathrm{L}$, there was a gradual and significant increase $(\mathrm{p}=0.0253)$ at percentage of immobilized organisms.

\subsection{Toxicological effects of ametryne to E. sativa and L. sativa seeds}

In order to evaluate the influence of ametryne on the land community, the effects of the herbicide on E. sativa and L. sativa seeds were analyzed at different concentrations (Table 3 
and Table 4).

Table 3. Phytotoxicity with ametryne for E. sativa seeds.

\begin{tabular}{cccc}
\hline $\begin{array}{c}\text { Concentration of ametryne } \\
(\mathrm{g} / \mathrm{L})\end{array}$ & $\begin{array}{c}\text { Germination of } \\
\text { seeds }(\%)\end{array}$ & $\begin{array}{c}\text { Growth of root } \\
(\mathrm{cm})\end{array}$ & $\begin{array}{c}\text { Inhibition of growth } \\
\text { of root }(\%)\end{array}$ \\
\hline Negative control & 100 & $31.75^{\mathrm{a}} \pm 0.12$ & 0.00 \\
0.25 & 70 & $20.90^{\mathrm{b}} \pm 0.21$ & 34.17 \\
0.50 & 70 & $17.80^{\mathrm{c}} \pm 0.66$ & 43.93 \\
1.00 & 65 & $16.55^{\mathrm{d}} \pm 0.25$ & 47.87 \\
5.00 & 50 & $14.20^{\mathrm{e}} \pm 0.48$ & 55.27 \\
10.00 & 45 & $10.10^{\mathrm{f}} \pm 0.40$ & 68.18 \\
Positive control & 100 & $0.00^{\mathrm{g}} \pm 0.00$ & 100.00 \\
\hline
\end{tabular}

The means followed by the same letter, do not differ by Tukey's test at 5\% probability

It was observed an increased in growth inhibition of $E$. sativa root related to the increase of ametryne concentrations. Even in small concentrations, such as $0.25 \mathrm{~g} / \mathrm{L}$, the ametryne caused inhibitory about $35 \%$ in root growth.

E. sativa had a sensitivity to the herbicide, even in small amounts. At three variables evaluated the germination, growth of root and inhibition of growth of root, the seed was suffering from negative.

The concentration of $5.00 \mathrm{~g} / \mathrm{L}$ and $10.00 \mathrm{~g} / \mathrm{L}$ caused more than $55 \%$ inhibitory effect on root growth. The germination variable showed less sensitivity to the presence of ametryne, however, the concentration $10.00 \mathrm{~g} / \mathrm{L}$, interfered in $45 \%$ germination capacity of E. sativa.

At $0.25 \mathrm{~g} / \mathrm{L}$ concentration, $34.64 \%$ seeds of E. sativa suffered toxic effects on root growth. However, for $L$. sativa seed, only $1.40 \%$ suffered adverse effects on root growth. The Table 4 shows the results for toxicity using seeds of $L$. sativa.

Table 4. Phytotoxicity with ametryne for $L$. sativa seeds.

\begin{tabular}{cccc}
\hline $\begin{array}{c}\text { Concentration of ametryne } \\
(\mathrm{g} / \mathrm{L})\end{array}$ & $\begin{array}{c}\text { Germination of } \\
\text { seeds }(\%)\end{array}$ & $\begin{array}{c}\text { Growth of root } \\
(\mathrm{cm})\end{array}$ & $\begin{array}{c}\text { Inhibition of growth } \\
\text { of root }(\%)\end{array}$ \\
\hline Negative control & 100 & $31.35^{\mathrm{a}} \pm 0.14$ & 0.00 \\
0.25 & 75 & $20.7^{\mathrm{b}} \pm 0.19$ & 33.97 \\
0.50 & 70 & $19.4^{\mathrm{b}} \pm 0.17$ & 38.11 \\
1.00 & 60 & $16.5^{\mathrm{c}} \pm 0.14$ & 47.36 \\
5.00 & 55 & $15.9^{\mathrm{c}} \pm 0.16$ & 49.28 \\
10.00 & 55 & $11.7^{\mathrm{d}} \pm 0.13$ & 62.67 \\
Positive control & 0.00 & $0.00^{\mathrm{e}} \pm 0.00$ & 100.00 \\
\hline
\end{tabular}

It was observed that with the increase in ametryne concentration there was an increase in phytotoxicity for L. sativa seeds. Concentrations from $0.25 \mathrm{~g} / \mathrm{L}$ to $0.50 \mathrm{~g} / \mathrm{L}$ had no significant 
differences in root growth. There was a root inhibition growth about $20 \%$ in concentrations between $1.00 \mathrm{~g} / \mathrm{L}$ and $5.00 \mathrm{~g} / \mathrm{L}$. The ametryne phytotoxicity for $L$. sativa results showed significant effect on seeds even at low herbicide concentrations.

With the increase in concentrations, little difference occurred between the results of germination. However, at concentrations of $5.00 \mathrm{~g} / \mathrm{L}$ and $10.00 \mathrm{~g} / \mathrm{L}$ the ametryne prevented the germination of seeds over half of the samples $L$. sativa.

The inhibition percentage on root growth seed, was the most sensitive among tests. The increase in growth inhibition concentrations of $0.25 \mathrm{~g} / \mathrm{L}$ and $0.50 \mathrm{~g} / \mathrm{L}$ was significant $(\mathrm{p}<$ $0.05)$.

The concentration of $10.00 \mathrm{~g} / \mathrm{L}$ caused major negative effects on the development of L. sativa, reducing about $60 \%$ compared to negative control, in the root growth.

\section{Discussion}

Even at low concentration (Table 2), ametryne caused toxic effects on D. similis. Gutierrez et al. (2013) behold that atrazine herbicide were highly toxic to aquatic organisms as Mesocyclops longisetus, even at low concentrations.

The concentration that caused mobility $50 \%$ of organisms was $25.73 \mathrm{mg} / \mathrm{L}$ for $D$. similis. For Daphnia magna, Farré et al. (2002) observed that ametryne caused $28 \mathrm{mg} / \mathrm{L}$ toxic effect.

From the concentration $50.00 \mathrm{mg} / \mathrm{L}$ organisms not present mobility. This was observed by Sánchez-Bayo (2006), concluding that the ametryne is very toxic to crustaceans as brine shrimp, resulting in LC 50 of $20-50 \mathrm{mg} / \mathrm{L}$, once that, in average, the toxicity of triazine herbicides to Cladocera order is about $43 \mathrm{mg} / \mathrm{L}$.

The D. similis is a representative organism for ecotoxicity tests. With increasing concentrations ametryne added in its growing water showed sensitivity interfering with the functions of their bodies, such as immobility and death.

The seeds L. sativa and E. sativa, they suffered toxic effects of ametryne even in low concentrations. The same was observed by Régo et al. (2014), that even in low concentrations in soil, ametryne caused reduced growth of the root $L$. sativa.

However, the seed E. sativa showed higher sensitivity compared to seed L. sativa. The ametryne interfered in the germination and root growth of seeds evaluated. All variables were negatively affected by the presence of the herbicide.

The ametryne is classified as a FSII herbicide, that is, extremely phytotoxic, inhibiting the electron transport chain of chloroplasts, even in low concentrations, becoming a threat to the aquatic environment (Sandoval-Carrasco et al., 2013; USEPA, 2005).

\section{Conclusion}

The ametryne result in toxic effects to the assessed organisms. The organisms D. similis suffered interference in its immobility, even at low concentrations of herbicide. 


\section{Macrothink}

Aquatic Science and Technology

ISSN 2168-9148 2018, Vol. 6, No. 1

L. sativa and E. sativa seeds were sensitive to the presence of ametryne, because both suffered interference in its development during germination, root growth and inhibition of their growth.

Thus, it is necessary remedial measures for contaminated sites with ametryne in order to reduce the negative effects on aquatic and terrestrial ecosystems.

\section{Acknowledgment}

Coordination Personnel Perfectioning Higher Education - CAPES- CnPQ.

\section{Conflicts of interest}

There are no conflicts of interest in this research.

\section{References}

ABNT, Brazilian Association of Technical Standards. (2004). Ecotoxicology Aquatic- Acute toxicity. Test method with Daphnia similis. $\mathrm{n}^{\circ} 12713$.

Botelho, R. G., Monteiro, S. H., Christofoletti, G. C., Moura-Andrade, R., \& Tornisielo, V. L. (2015). Environmentally Relevant Concentrations of Atrazine and Ametrine Induce Micronuclei Formation and Nuclear Abnormalities in Erythrocytes of Fish. Archives of Environmental Contamination and toxicology, 69, 577-585. https://doi.org/10.1007/s00244-015-0171-6

Bruzzoniti, M. C., Sarzanini, C., Constantino, G., \& Fungi, M., (2006). Determination of herbicides by solid phase extraction gas chromatography-mass spectrometry in drinking waters. Analytica Chimica Acta, 578, 241-249. https://doi.org/10.1016/j.aca.2006.06.066

Faust, M., Altenburger, R., Backhaus, T., Blanck, H., Boedeker, W., Gramatica, P., Hamer, V, Scholze, M., Vighi, M., \& Grime, L. M. (2003). Joint algal toxicity of 16 dissimilarly acting chemicals is predictable by the concept of independent action. Aquatic Toxicology, 63, 43-63. https://doi.org/10.1016 / S0166-445X (02) 00133-9

Farré, M., Fernandez, J., Paez, M., Granada, L., Barba, L., Gutierrez, H.M., Pulgarin, C., \& Barceló, D. (2002). Analysis and toxicity of methomyl and ametryn after biodegradation. $\begin{array}{llll}\text { Analytical and Bioanalytical } & \text { Chemistry, } & 373,\end{array}$ https://doi.org/10.1007/s00216-002-1413-9

Gafar, M. O., Yagi, M. I., \& Elhag, A. Z. (2013). The Effect of Malathion and Sevin Pesticides Application on Soil and Garden Rocket (Eruca Sativa L.) Growth. Universal Journal of Applied Science, 1, 82-85. https://doi.org/10.13189/ujas.2013.010302

Gao, N., Deng, Y., \& Zhao, D. (2009). Ametryn degradation in the ultraviolet (UV) irradiation/hydrogen peroxide $\left(\mathrm{H}_{2} \mathrm{O}_{2}\right)$ treatment. Journal of Hazardous Materials, 164, 640-645. https://doi.org/10.1016 / j.jhazmat.2008.08.038 
Gutierrez, M. F., Gagneten, A. M., \& Paggi, J. C. (2013). Acute and Behavioral Sensitivity of Mesocyclops longisetus to Atrazine and Endosulfan Formulations under Predation Pressure. Water Air Soil Pollution, 224, 2-9. https://doi.org/10.1007/s11270-012-1375-2

Hamilton, M. A., Russo, R. C., \& Thurston, R. V. (1977). Trimmed Spearman-Karber method for estimating median lethal concentration in toxicity bioassays. Environmental Science \& Technology, 11, 714-719.

Herrera, N., Palacio, J., Echeverri, F. \& Ferrão-Filho, A. (2014). Effects of a cyanobacterial bloom sample containing microcystin-LR on the ecophysiology of Daphnia similis. Toxicology Reports, 1, 909-914. https://doi.org/10.1016 / j.toxrep.2014.10.017

Kasozi, G. N., Nkedi-Kizza, P., Li, Y., \& Zimmerman, A. R. (2012). Sorption of atrazine and ametryn by carbonatic and non-carbonatic soils of varied origin. Environmental Pollution, 169, 12-19. https://doi.org/10.1016/j.envpol.2012.05.002

Koskinen, W. C., \& Harper, S. S. (1990). The retention process: mechanisms. Pesticide in the soil environment: processes, impacts, and modeling. In CHENG, H. H. (ed.) Soil Science Society of America. (51-78). Madison.

Kurth, D., Biack, W., \& Luckenbach, T. (2015). Is chemosensitisation by environmental pollutants ecotoxicogically relevant?. Aquatic Toxicology. 167, 134-142. https://doi.org/10.1016/j.aquatox.2015.07.01

Laabs, V., Amelung, W., Pinto, A. A., Wantzen, M., Silva, C. J., \& Zech, W. (2002). Pesticides in Surface Water, Sediment, and Rainfall of the Northeastern Pantanal Basin, Brazil. Journal of Environmental Quality, 31, 1636-1648. https://doi.org/10.2134/jeq2002.1636

Malinowska, E., \& Jankowski, K. (2015). Pesticide residues in some herbs growing in agricultural areas in Poland. Environmental Monitoring and Assessment, 187, 1-7. https://doi.org/10.1007/ s10661-015-4997-1.

Novelli, A., Vieira, B. H., Vasconcelos, A. M., Peret, A. C., \& Espíndola, E. L. G. (2012). Field and laboratory studies to assess the effects of Vertimec ${ }^{\circledR} 18 \mathrm{EC}$ on Daphnia similis. Ecotoxicology Environmental Safety, 75, 87-93. https://doi.org/10.1016/j.ecoenv.2011.08.016

OCDE-FAO. Organisation for Economic Co-operation and Development. Food and Agriculture Organization of the United Nations. (2015). Agricultural Perspectives. 2015-2024. Brazilian Agriculture: Prospects and challenges. https://doi.org/10.1787/agr_outlook-2015-en

Pfeuffer, R. J., \& Rand, G. M. (2004). South Florid ambient pesticide monitoring program. Ecotoxicology, 13, 195-205. https://doi.org/10.1023/B:ECTX.0000023565.91904.20

Régo, A. P. J., Reganhan-Coneglian, C. M., Montagnolli, R. N., \& Bidoia, E. D. (2014). $\mathrm{CO}_{2}$ production of soil microbiota in the presence of ametryne and biofertilizer. Water Air Soil Pollution, 225, 1-6. https://doi.org/10.1007/s11270-014-2222-4

Sánches-Bayo, F. (2006). Comparative acute toxicity of organic pollutants and reference 


\section{Macrothink}

Aquatic Science and Technology

ISSN 2168-9148

2018, Vol. 6, No. 1

values for crustaceans. I. Branchiopoda, Copepoda and Ostracoda. Environmental Pollution. 139, 385-420. https://doi.org/10.1016/j.envpol.2005.06.016

Sandoval-Carrasco, C. A., Chacón-Ahuatzi, D., Mayer-Galíndez, J., Ordaz-Ruiz, N., Ramírez-Juárez, C., \& Jeronímo-Martínez, F. (2013). Biodegradation of a mixture of the herbicides ametryne, and 2, 4-dichlorophenoxyacetic acid (2,4-D) in a compartmentalized biofilm reactor. Bioressource Technology, 33-36. https://doi.org/10.106/j.biortech.2013.02.068

Schwarzenbach, R. P., Gschwend, P. M., \& Imboden, D. M. (2003). Environmental organic chemistry. 2nd ed. New-Jersey, NJ: Wiley- Interscience.

Sobrero, M. C., \& Ronco, A. (2004). Acute toxicity test com Lettuce seeds (Lactuca sativa L.). In Morales G. C. (ed). Toxicological testing and evaluation methods of water quality: standardization, intercalibration, results and applications. (71-79). México: IMTA.

USEPA, United States Environment Protection Agency. (2005). Reregistration eligibility decision (RED) for ametryn. Prevention, Pesticides and toxic substances. $\mathrm{n}^{\circ}$ 738-R-006.

Velki, M., \& Ečimović, S. (2015). Changes in exposure temperature lead to changes in pesticide toxicity to earthworms: A preliminary study. Environmental Toxicology and Pharmacology, 40, 774-784. http://dx.doi.10.1016/j.etap.2015.09.009

\section{Copyrights}

Copyright for this article is retained by the author(s), with first publication rights granted to the journal.

This is an open-access article distributed under the terms and conditions of the Creative Commons Attribution license (http://creativecommons.org/licenses/by/4.0/) 